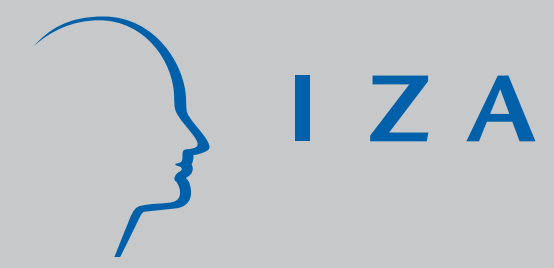

IZA DP No. 3818

"Every Catholic Child in a Catholic School": Historical Resistance to State Schooling, Contemporary Private Competition, and Student Achievement across Countries

\author{
Martin R. West \\ Ludger Wößmann
}

November 2008 


\title{
"Every Catholic Child in a Catholic School": Historical Resistance to State Schooling, Contemporary Private Competition, and Student Achievement across Countries
}

\author{
Martin R. West \\ Brown University \\ Ludger Wößmann \\ University of Munich, Ifo Institute, \\ CESifo and IZA
}

Discussion Paper No. 3818

November 2008

\author{
IZA \\ P.O. Box 7240 \\ 53072 Bonn \\ Germany \\ Phone: $+49-228-3894-0$ \\ Fax: +49-228-3894-180 \\ E-mail: iza@iza.org
}

\begin{abstract}
Any opinions expressed here are those of the author(s) and not those of IZA. Research published in this series may include views on policy, but the institute itself takes no institutional policy positions.

The Institute for the Study of Labor (IZA) in Bonn is a local and virtual international research center and a place of communication between science, politics and business. IZA is an independent nonprofit organization supported by Deutsche Post World Net. The center is associated with the University of Bonn and offers a stimulating research environment through its international network, workshops and conferences, data service, project support, research visits and doctoral program. IZA engages in (i) original and internationally competitive research in all fields of labor economics, (ii) development of policy concepts, and (iii) dissemination of research results and concepts to the interested public.
\end{abstract}

IZA Discussion Papers often represent preliminary work and are circulated to encourage discussion. Citation of such a paper should account for its provisional character. A revised version may be available directly from the author. 
IZA Discussion Paper No. 3818

November 2008

\section{ABSTRACT \\ "Every Catholic Child in a Catholic School": Historical Resistance to State Schooling, Contemporary Private Competition, and Student Achievement across Countries}

Nineteenth-Century Catholic doctrine strongly opposed state schooling. We show that countries with larger shares of Catholics in 1900 (but without a Catholic state religion) tend to have larger shares of privately operated schools even today. We use this historical pattern as a natural experiment to estimate the causal effect of contemporary private competition on student achievement in cross-country student-level analyses. Our results show that larger shares of privately operated schools lead to better student achievement in mathematics, science, and reading and to lower total education spending, even after controlling for current Catholic shares.

JEL Classification: $\quad$ 120, L33, N30, Z12

Keywords: $\quad$ private school competition, student achievement, Catholic schools

Corresponding author:

Ludger Wößmann

ifo Institute for Economic Research

at the University of Munich

Poschingerstr. 5

81679 Munich

Germany

E-mail: woessmann@ifo.de

\footnotetext{
* We are grateful to Charles Glenn for providing important background information, to Elke Lüdemann and Gabriela Schütz for their contributions in preparing the PISA 2003 database, and to Caroline Hoxby, Mikael Lindahl, Hessel Oosterbeek, and other participants at the CESifo/PEPG conference in Munich for helpful comments.
} 


\section{Introduction}

The officials of the Catholic Church in the United States convened at the Third Plenary Council of Baltimore in 1884 against a backdrop of social conflict engendered by the advent of mass public education. The ongoing push to establish "common schools" had produced a vast network of government-run schools which, while ostensibly non-sectarian, in fact embraced an approach to moral and religious instruction that Catholic leaders and many of their followers found objectionable. Efforts to win equitable treatment for parochial schools with respect to government funding had provoked a backlash of constitutional provisions prohibiting aid to religious schools in most American states (Viteritti 1998). Yet the Council only strengthened its commitment to establish a parallel system of private schools for American Catholics. Taking heed of pronouncements on education from the Vatican, it reaffirmed the "absolute necessity and the obligation of pastors" to maintain distinctively Catholic schools and ordered that every parish open such a school within two years. It also decreed that "parents must send their children to such schools unless the bishop should judge their reason for sending them elsewhere to be sufficient” (Herbermann 1912). Their goal, the bishops famously declared, was no less than to see "every Catholic child in a Catholic school” (Reuben 2005).

The American clerics were not unique in their resistance to the rise of state school systems. Since the early $19^{\text {th }}$ Century, official Catholic doctrine had emphasized the responsibility of local parishes to ensure that all Catholic children received a Catholic education. Where the instruction offered in emerging state education systems was inconsistent with Catholic teachings, parishes worked to establish private schools and lobbied governments to provide financial support for their efforts. As we will demonstrate below, even today countries that historically had larger shares of Catholics, but where Catholicism was not the official state religion, tend to have larger shares of privately operated schools.

In this paper, we exploit this relationship between early resistance to state schooling and the current extent of private schooling to examine the effect of competition on student achievement across countries. In particular, we draw upon contemporary variation in private school enrollment that is related to differences in the share of a country's population that was Catholic at the end of the $19^{\text {th }}$ Century. We argue that these historical differences provide a natural experiment that allows for the identification of causal effects of private school competition on the performance of national school systems. 
The appropriate role of the private sector in the provision of schooling remains one of the most hotly contested governance issues among education researchers and policymakers worldwide. Proposals for vouchers, tuition tax credits, and other mechanisms to expand access to private schooling are often justified on the grounds that enhanced competition from private schools will strengthen incentives for innovation and cost containment within the public sector, lifting student achievement system-wide (e.g., Friedman 1962; Neal 2002). Critics of such policies, on the other hand, note that the educational benefits of competition are unproven and argue that a greater reliance on private schooling will lead to increased segregation of students along lines of ability, ethnicity, or class (e.g., Brighouse 2000; Ladd 2002).

Although there is considerable international variation in the share of students attending private schools, existing evidence on the effects of private competition on student achievement across countries is limited, for obvious reasons. In addition to the scarcity of comparable data on achievement and competition, the challenges researchers have faced include the possibility of unobserved differences in student characteristics correlated with private schooling and the potential endogeneity of private enrollment to public school quality. If demand for private schooling reflects aspects of socioeconomic status that are not perfectly measured, then partial correlations between competition and public school quality will suffer from omitted variables bias. Moreover, even well-controlled comparisons of countries with small and large private sectors will be biased to the extent that low-quality public schools increase demand for private schooling as a substitute.

The identification strategy developed in this paper, which we implement using student-level data from 29 member countries of the Organisation for Economic Cooperation and Development (OECD) that participated in the PISA 2003 study of student achievement, is intended to address these concerns. We use the share of Catholics in 1900 (interacted with a variable indicating that Catholicism was not the state religion at that time) as an instrumental variable for a country's contemporary share of private schools to identify the effect of competition from private schools on student achievement. The historical nature of the instrument allows us to control directly for any effect that the current Catholic share has on student outcomes. While our measure of the extent of private school competition is at the country level, we use the PISA 2003 student-level database to control for an unusually rich set of student and school background factors. 
Our results indicate that the share of schools that are privately operated has an economically and statistically significant positive effect on student achievement in mathematics, science, and reading, even after controlling for the current levels of Catholics and for the share of funding that privately operated schools receive from the government. In fact, the current share of Catholics is negatively related to student achievement in the second-stage model, suggesting that distinctive cultural features of traditionally Catholic countries are unlikely to be driving our results. Our results further suggest that much of the benefit of private competition accrues to students in public schools. Finally, we find that private competition reduces educational expenditure per student in the system, so that the better educational outcomes are obtained at lower cost.

Most of the prior literature examining the effect of private school competition on student outcomes comes from the United States. Studies exploiting differences in the size of the private sector related to contemporary differences in the density of Catholic population in order to make inferences about the effects of competition from private schools include Hoxby (1994), Dee (1998), Sander (1999), and Jepsen (2002). ${ }^{1} \quad$ A much smaller body of cross-country evidence addresses the effect of competition from private schools on system-wide performance at the national level, including Wößmann (2003, 2008) and Wößmann, Lüdemann, Schütz, and West (2007). ${ }^{2}$ Using different datasets, each of these studies finds a strong positive correlation between the share of schools that are privately managed and the level of student achievement across countries. To our knowledge, the current paper represents the first rigorous evidence that this relationship is, in fact, causal.

The paper proceeds as follows. Section 2 documents Catholic doctrine towards state schooling in the $19^{\text {th }}$ Century and shows how it stimulated the emergence of private schools in several countries, despite the fact that predominantly non-Catholic countries were more educationally advanced. Section 3 presents our estimation strategy and data. Section 4 reports our results on the effect of private school competition on student achievement and educational expenditure. Section 5 concludes.

${ }^{1}$ See Belfield and Levin (2002) for a review of the literature on this topic, as well as of related work on the effects of competition among public schools.

${ }^{2}$ Toma (1996) and Vandenberghe and Robin (2004) present evidence comparing achievement in public and private schools within several countries. 


\section{Catholic Doctrine as an Historical Source of Private Schooling}

Our identification strategy exploits the fact that historical differences in the Catholic share of the population across countries led to persistent differences in the size of the private school sector. This section provides historical evidence from several countries that reveals the mechanisms underlying this relationship. We also show that, if anything, adherence to the Catholic faith has been negatively associated with educational and economic development, attenuating concerns that historical Catholic shares capture other features conducive to education.

\subsection{Catholic Doctrine on State Schooling in the $19^{\text {th }}$ Century}

The late- $18^{\text {th }}$ and $19^{\text {th }}$ Centuries saw the emergence and rapid institutionalization of a standard model of state-sponsored mass education across virtually all industrializing countries (Ramirez and Boli 1987). Common characteristics of the education systems constructed during this period included the explicit recognition of a national interest in an educated population, compulsory schooling laws, the creation of a state education bureaucracy with authority over existing and new schools, and a growing share of schools operated directly by the state. This model emerged first in Western Europe but by 1900 had spread throughout the industrialized world.

Over the course of the $19^{\text {th }}$ Century, the Vatican authorities expressed increasing concern over the implications of these emerging state systems for the moral and religious training of Catholics. For example, among the propositions included in the Syllabus Errorum, the list of commonly held beliefs condemned by Pope Pius IX in 1864, was the notion that "Catholics may approve of the system of educating youth unconnected with Catholic faith and the power of the Church.” Thus, the pope declared it an error to conclude that Catholics could send their children to state-run schools outside the supervision of the Catholic Church. Related claims also denounced in the Syllabus include those that "The entire government of public schools ... may and ought to pertain to the civil power" and that "popular schools open to children of every class of the people ... should be freed from all ecclesiastical authority, control and interference.”

Catholic doctrine did not deny that the state had a legitimate interest in ensuring that all members of the public received an education of sufficient quality to maintain the public welfare. It therefore accepted compulsory attendance laws and acknowledged the right of the state to 
monitor even Church-run schools in order to make certain that they complied with public health standards and did not teach politically subversive doctrines. It also considered it appropriate for the government to collect taxes to support state schools, provided that such funds were shared with Catholic schools on an equitable basis (Herbermann 1912).

This was rarely the case, however, and the Vatican repeatedly emphasized that the lack of equitable funding did not absolve parents of the responsibility to secure an appropriate (i.e., Catholic) education for their children. Pope Leo XIII, in his 1884 encyclical On the Religious Question in France, wrote that the Church "has always expressly condemned mixed or neutral schools; over and over again she has warned parents to be ever on their guard in this most essential point.” The Catholic Encyclopedia, published during the pontificate of Pope Pius X in 1912 as a summary of official Catholic doctrine, stated that the "State monopoly of education has been considered by the Church to be nothing short of a tyrannical usurpation” (Herbermann 1912, p. 558). ${ }^{3}$

\subsection{Catholic Resistance to State Schooling in Specific Countries}

The Vatican's formal pronouncements concerning education constituted binding mandates for Catholic officials at the national level, who in turn devoted considerable resources to the creation of privately operated Catholic schools. In the United States, for example, the 1884 meeting of the Third Plenary Council discussed above sparked the most rapid construction of parochial schools in the nation's history. By 1911, there were almost 5,000 parochial schools serving more than 1.27 million students nationwide (Herbermann 1912). Although American Catholic schools never enrolled more than a small fraction of the national student population, as late as 1980 they accounted for almost 80 percent of enrollment in private elementary and secondary schools (Hoxby 1994).

The late- $19^{\text {th }}$ Century historical record of other countries is likewise filled with evidence of Catholic efforts to construct and maintain independent school systems in the face of growing

\footnotetext{
${ }^{3}$ Interestingly, the language concerning parental obligations in Gravissimum Educationis, the Second Vatican Council's 1965 decree on education, is far softer than that of the Church's $19^{\text {th }}$ Century pronouncements: "The Council also reminds Catholic parents of the duty of entrusting their children to Catholic schools wherever and whenever it is possible and of supporting these schools to the best of their ability and of cooperating with them for the education of their children.”
} 
state hostility. In predominantly Catholic Belgium, for example, after the nation won its independence in 1830, the Church had either maintained its own schools with the support of public funds or exercised strong influence over the curriculum in municipal schools. Yet the elite-dominated Liberal party, viewing state schooling "the primary instrument of popular enlightenment” (Glenn 1989, p. 84), in 1879 banned subsidies for Catholic schools and required all municipalities to establish public schools that would replace religious instruction with secular moral training. Belgian Catholics responded by removing their children from the public schools and erecting their own, parallel system. The share of Belgian elementary school students in Catholic schools rose from 13 percent in 1878 to 61 percent just two years later (Glenn 1989, p. 85). In 1884, the Catholic party regained a legislative majority and immediately returned control of schooling to the municipalities, allowing them to adopt or subsidize Catholic private schools within their jurisdiction.

In the neighboring Netherlands, where Catholics made up only about one-third of the population, they allied with Calvinists who were equally dissatisfied with the nondenominational instruction available in the state sector in order to secure government funding for privately operated religious schools. In 1878, the Liberal party had adopted new staffing and physical requirements for all schools and established subsidies for municipal schools only. Both changes threatened the continued existence of confessional schools and provoked an intense popular response. By 1888, the Catholics and Calvinists had acquired a majority in the Parliament and the following year they adopted the same 30 percent national subsidy for confessional schools. In 1917, the Dutch Constitution was amended to guarantee equal funding for any school meeting general enrollment and quality standards, without regard to whether the school was publicly or privately operated. The share of Dutch students attending privately operated schools accordingly increased from 25 percent in 1880, to 38 percent in 1910, to 73 percent in 1940 (Glenn 1988).

The British government was relatively slow to become involved in the provision of education (Glenn 1989; West 2000). After Local Education Authorities were established in 1882 to fill up the gaps in the existing system, voluntary religious schools were gradually incorporated into the public system. The exception within the United Kingdom as it existed in the late $19^{\text {th }}$ Century was Ireland, where the British government had in 1831 financed the creation of a system of nondenominational "National Schools" in an unsuccessful attempt to assimilate the 
predominantly Catholic population. Although many Irish Catholics initially responded favorably, their position hardened in the 1850s when the hierarchy decreed that "only schools under Catholic auspices could be regarded as satisfactory for the education of young Catholics” (Akenson 1970, p. 224). In response, the British government made a series of accommodations, such as allowing the display of denominational symbols in the national schools (Farren 1995). The system that emerged once the Irish Republic gained independence in 1919 provided public funding for denominational schools subject to government regulation, but operated privately by religious congregations or independent governing boards (Glenn 1989).

Protestant Christians in most countries were less resistant to state control of mass education. There are important exceptions, such as the Calvinists in the Netherlands, who rejected the lowest-common-denominator Protestantism available in state schools and joined forces with the Catholics in advocating for public subsidies for their own schools. However, as a general rule, Protestant denominations lacked formal doctrines mandating that schooling be under their exclusive control and were more willing to pursue their educational goals within the framework created by the emerging state systems.

The early German experience nicely illustrates the often divergent responses of Catholics and Protestants to the advent of state involvement in education. As the Catholic Encyclopedia explains, "After the reformation in Germany the primary schools in Protestant provinces passed over to the control of the local civil authorities. In Catholic communities the ecclesiastical authorities did not yield so readily to the aggression of the State” (Herberman 1912, p. 558). When the Prussian government mandated compulsory attendance at public schools in 1794, it allowed for these schools to be denominational and effectively operated by the Church. Within this system, schools in Protestant areas again proved more accepting of steadily increasing government regulation: "There was little likelihood, during the $19^{\text {th }}$ Century, of the Protestant churches - committed to an alliance of Throne and Altar - taking an independent line in education” (Glenn 1989, p. 193). In contrast, the government's attempt to ban religious teaching orders from the schools in the 1870s provoked an intense response from Catholics that ensured that the German public schools would retain their denominational character.

In short, in the late $19^{\text {th }}$ Century, the distinctive Catholic doctrine emphasizing the obligation of local parishes and parents to ensure that every Catholic child received a Catholic education spurred efforts to establish and maintain private schools in a variety of countries and, in some 
contexts, to adopt policies benefiting private schools more generally. Predictably, these efforts were most successful in countries where Catholics represented at least a substantial minority of the nation's population. Countries where Catholicism was the official state religion throughout this period are an obvious but important exception to this pattern, as Catholics in these nations did not need to create private schools in order to comply with their religion's dictates. Italy, Luxemburg, Portugal, and Spain, four of the nations in our dataset where Catholicism was the official state religion in 1900, all remain nominally Catholic today.

\subsection{Catholicism and Educational Progress}

The analysis below uses these historical patterns to isolate contemporary variation in the extent of private school competition across countries that is otherwise unrelated to contemporary student achievement. In taking this approach, we assume that the density of Catholics in 1900 is not directly related to student achievement today, independent of any indirect effects through school competition. Of course, this assumption is impossible to test definitively.

It has been well documented, however, that Protestant Christians have traditionally placed a far greater emphasis than have Catholics on the value of education, in particular as a means to facilitate individual Bible reading (e.g., Green 1979; Rupp 1996; Becker and Wößmann 2008). In fact, across the 22 countries with a Christian majority for which literacy data are available, there is a strong negative association between Catholic population shares and literacy rates in $1900(r=-0.75, p$-value $=0.0001)$. The Catholic share was also negatively correlated with GDP per capita in 1900 ( $r=-0.54, p$-value $=0.002,29$ countries). But even after controlling for percapita GDP, the strong negative association between Catholicism and literacy persists. ${ }^{4}$ Thus, to the extent that differences in cultural values related to religion bias our results, they should make us less likely to find beneficial effects of private school competition induced by Catholicism on educational outcomes.

The historical prevalence of Catholicism could also have had other consequences, apart from a greater reliance on private schooling, that affect student achievement. If so, the most likely pathways would seem to run through current GDP per capita or education spending per student.

\footnotetext{
${ }^{4}$ These correlations include all countries with available data on literacy rates and GDP per capita, respectively, in which Catholics and Protestants together accounted for the majority of the population (see Becker and Wößmann 2008 for data sources). The same correlations hold within the sample of OECD countries used in our analyses.
} 
We therefore control for both of these variables in all models relating Catholic shares, private schooling, and achievement. We also examined whether the Catholic Church's emphasis on subsidiarity, or the principle that social programs should be administered at the lowest possible level, may have shaped the development of national education systems. Perhaps surprisingly, the Catholic population share in 1900 is not significantly correlated with the percentage of current school policy decisions (as documented in OECD 2004a) made at the national or school level (as opposed to regional or local levels) and is in fact negatively correlated with the percentage of decisions made at the local level. Nor is the Catholic share in 1900 significantly correlated with either current public social expenditure or with current income inequality, two other possible indirect pathways of effects on educational outcomes. ${ }^{5}$ Including any of these measures individually as additional control variables in the models presented below does not substantively affect our results concerning the effects of private school competition on student achievement.

These patterns strongly support our assumption that Catholic population shares in 1900 are not positively related to current student achievement except for any indirect effect through their impact on private school competition. If anything, the negative association of Catholicism with historical educational and economic development may downwardly bias estimated effects of private competition drawing on variation induced by historical Catholic shares. Still, an important advantage of our use of historical variation in Catholic population shares is that we can address lingering concerns about the possibility that Catholicism has a direct influence on student achievement by controlling for contemporary differences in the share of Catholic adherents across countries.

\section{Estimation Strategy and Data}

This section discusses the formal specification of our cross-country instrumental variables model of the effects of private school competition on student achievement. It also introduces the PISA 2003 international student achievement database and other international data that we use to implement this model.

${ }^{5}$ Data on public social expenditure as a percentage of GDP in 2003 and on the distribution of household disposable income among individuals measured by Gini coefficients in 2000 are available in OECD (2008). 


\subsection{The Econometric Model}

Most existing international evidence on the relationship between private school competition and student achievement (e.g., Wößmann 2003, 2008; Wößmann, Lüdemann, Schütz, and West 2007) is based on cross-country education production functions of the following form:

$$
T_{i s c}=\alpha_{1}+\beta_{0} P_{c}+\mathbf{X}_{c} \beta_{1}+\mathbf{X}_{s c} \beta_{2}+\mathbf{X}_{\text {isc }} \beta_{3}+\varepsilon_{\text {isc }}
$$

where $T_{i c s}$ is the test score of student $i$ in school $s$ in country $c$. The country-level variable $P_{c}$, which represents the share of students attending privately operated schools, measures the extent of competition from private schools within each national school system. $\mathbf{X}_{c}$ is a vector of country-level control variables, $\mathbf{X}_{s c}$ is a vector of variables measuring school location and resources, and $\mathbf{X}_{i s c}$ is a vector of student-level variables measuring student and family background characteristics. Finally, $\varepsilon_{i c s}$ is a zero-mean error term adjusted to allow for the clustering of observations by country.

We begin our analysis with this same approach, taking the specification of the control model from Wößmann, Lüdemann, Schütz, and West (2007). The vector of student and family background characteristics consists of 31 variables, including such indicators as the student's gender and age, attendance of institutions of pre-primary education, immigration status, family status, and parental occupation and work status. The vector of variables measuring school location and resources comprises 9 variables such as class size, availability of materials, instruction time, teacher education, and city size. The vector of country-level variables includes per-capita GDP of the country, average expenditure per student, external exit exams, and an indicator for whether the country had a Communist government in 1970. Appendix Table A.1 provides a complete list of all control variables included in our models.

There are at least two potential concerns with interpreting ordinary least squares estimates of $\beta_{0}$ as the causal effect of private school competition on educational achievement. Most withincountry analyses of competitive effects (e.g., Hoxby 1994; Dee 1998) have emphasized the likely endogeneity of private school enrollment with respect to public school quality. All else equal, low-quality public schools should increase demand for private alternatives, biasing correlational studies against finding beneficial effects of competition. An equally important concern, especially in the context of cross-country studies, is the possibility of omitted variables correlated with both the extent of private schooling and student achievement. These omitted 
variables could include factors that increase the demand for private schooling or institutional or policy factors that affect its supply. Unlike the potential bias due to endogeneity, the expected direction of any bias resulting from omitted variables is unclear.

Our analysis addresses these concerns by using the share of each country's population that was Catholic in 1900 (interacted with an indicator for whether Catholicism was not the official state religion, so that observations from officially Catholic countries have a value of zero) as an instrument for our measure of contemporary private school competition. As suggested by the historical evidence presented above, the Catholic population share in 1900 is highly predictive of the extent of private schooling in 2003 - at least in those countries where Catholics could not rely on the fact that Catholicism was the official state religion in order to exercise control over the school system. And we argued that historical differences in Catholicism should not otherwise be related to contemporary student achievement, except perhaps in a negative way.

We implement this cross-country instrumental variables estimation strategy using two-stage least squares, where $P_{c}$ in the second-stage model (1) is the predicted value of the following firststage model:

$$
P_{c}=\alpha_{1}+\delta C a t h_{c}^{1900}+\mathbf{X}_{c} \beta_{4}+\mathbf{X}_{s c} \beta_{5}+\mathbf{X}_{\text {isc }} \beta_{6}+\varepsilon_{\text {ics }}
$$

which regresses the share of privately operated schools in $2003\left(P_{c}\right)$ on $\operatorname{Cath}^{1900}$, a measure of the share of the population of countries without Catholic state religion that was Catholic in 1900, and the other control variables.

As discussed above, one advantage of our use of historical data on Catholicism is that we can address any lingering concerns about the exogeneity of our instrument by controlling for the share of each country's population that is Catholic in 2000. Therefore, in some specifications we add this information as an additional country-level variable in equations (1) and (2), effectively identifying based on changes in Catholic population shares over the course of the $20^{\text {th }}$ Century.

Our use of information on the religious composition, and in particular our use of the Catholic share of the population, in order to isolate the causal effect of private school competition on student achievement is closely related to the identification strategies used in a series of papers examining the effects of private school competition in the United States. Hoxby (1994), Dee (1998), Sander (1999), and Jepsen (2002) all use some measure of the contemporary variation in the population density of Catholics in the United States as an instrument for private school competition in estimating effects on the quality of public schools, arguing that a greater 
concentration of Catholics reduces the cost of establishing private schools. ${ }^{6}$ Hoxby (1996), in the approach most similar in spirit to ours, uses the change between 1950 and 1980 in Catholic population shares as an instrument for the level of subsidies for private schooling.

We extend this literature by using an historical instrument that dates as far back as $1900 .^{7}$ That is, rather than using differences in religious adherence within the current population, we isolate variation in private school enrollment emanating from the historical implementation of traditional Catholic doctrine. ${ }^{8}$ Not only does our use of data on religious composition from 1900 increase confidence in the instrument's validity, it also allows us to control directly for the effects of contemporary religious composition when estimating the effects of private competition. In addition, the use of international data allows us to consider much wider variation in the extent of competition from private schooling than exists in the United States.

\subsection{International Data on Student Achievement and Religious Adherence}

The 2003 round of the OECD Programme for International Student Assessment (PISA) was conducted in 41 developed and emerging countries, 30 of which are members of the OECD. ${ }^{9}$ PISA 2003 assessed the mathematical, scientific, and reading literacy of the student population in each participating country. ${ }^{10}$ As in the first PISA study conducted in 2000, the target population was the 15-year-old students in each country, regardless of the grade they currently

${ }^{6}$ Gallego (2004) and Card, Dooley, and Payne (2007) use similar identification strategies in Chile and Canada, respectively. In related work, Evans and Schwab (1995), Neal (1997), Sander (1996), and Jepsen (2003) use similar indicators of Catholicism as instruments to estimate the relative effectiveness of Catholic and public schools. Altonji, Elder, and Taber (2005) present evidence that these instruments may not be valid in that setting.

7 The use of historical instruments to obtain exogenous variation in contemporary institutions is in a similar spirit as Acemoglu, Johnson, and Robinson (2001).

${ }^{8}$ Cohen-Zada (forthcoming) argues that the Catholic share of the population in 1890 (and its squared term) serve as a useful instrument for contemporary private school competition in the United States.

${ }^{9}$ For detailed information on the PISA study and its database, see OECD (2004b, 2005) and the PISA homepage at http://www.pisa.oecd.org.

10 The term "literacy" signifies that the study measured not only the knowledge of the students in each of the three domains, for example based on national curricula, but also their ability to use the acquired knowledge to meet real-life challenges. 
attended. Thus, in most participating countries, the target population consists of individuals nearing the last stages of compulsory schooling.

Importantly for our use of these data to make cross-country comparisons, the PISA sampling procedure ensured that a representative sample of the target population was tested in each country. ${ }^{11}$ According to the study protocol, a minimum of 150 schools were required to be sampled and a minimum of 4,500 students to be assessed in each country. The final sample size varied considerably between participating countries, ranging from 3,350 students in 129 schools in Iceland to 29,983 students in 1,124 schools in Mexico. We weight all regressions by sampling probabilities to obtain consistent student population estimates within each country. Across countries, each country carries the same aggregate weight. ${ }^{12}$

The main focus of the PISA 2003 study was on mathematical literacy, with about 70 percent of testing time devoted to this domain. The remainder of the testing focused on science and reading literacy. The test items were presented to the students in the form of booklets that varied in the composition of clusters of test items. Item response theory scaling was then used to calculate proficiency scores in each of the tested domains for each participating student. These scores were mapped on a scale with an international mean of 500 and a standard deviation of 100 test-score points across OECD countries.

PISA 2003 not only provides achievement data for representative samples of students in the participating countries but also a rich array of background information on each student and on the student's school. In separate background questionnaires, students were asked to provide information on their personal characteristics and family backgrounds, and school principals provided information on their schools' resource endowments and institutional settings.

${ }^{11}$ Most countries employed a two-stage sampling technique. The first stage drew a (usually stratified) random sample of schools in which 15-year-old students were enrolled. In most countries, the probability of the schools to be selected was proportional to their size as measured by the estimated numbers of 15-year-old students enrolled in the school. The second stage randomly sampled 35 of the 15-year-old students in each of these schools, with each 15-year-old student in a school having equal selection probability.

12 This weighting scheme ensures that each system-level observation of the extent of private competition contributes equally to the estimation. Weighting countries by student population sizes would lead to the results being dominated by a few large countries, especially the United States (with 28 percent of 15-year-old students across the 29 countries), Japan (11 percent), and Mexico (9 percent). Even so, our main results are robust to weighting by population sizes, although the instrument is weaker if (and only if) the United States is included. 
In particular, the PISA database provides an indicator for whether each student's school is privately operated (as well as the share of its funding that it receives from government sources). School principals reported whether their school is a private school, defined as being managed directly or indirectly by a non-government organization (e.g., a church, trade union, business, or other private institution), or a public school, defined as being managed directly or indirectly by a public education authority, government agency, or governing board appointed by government or elected by public franchise. In our analyses, we use this variable aggregated to the country level as our measure of private school competition.

Combining the available data, we constructed a dataset containing about 220,000 students in 29 of the 30 OECD countries. ${ }^{13}$ The dataset combines students' test scores in mathematics, science, and reading with students' characteristics, family-background data, and school characteristics. We imputed missing observations on the questionnaire items using the conditional mean imputation method (cf. Little and Rubin 1987) described in Wößmann, Lüdemann, Schütz, and West (2007, Appendix B.3). To ensure that our results are not biased by the inclusion of imputed observations, all regression specifications include separate dummy variables identifying observations with imputed data on each variable as well as interactions between these dummies and the relevant variable.

We supplement this rich student- and school-level database from PISA 2003 with additional country-level data. Crucially for our identification strategy, data on the Catholic population share of each country in 1900 and 2000 and indicators of countries with state religions are available from Barrett, Kurian, and Johnson (2001). ${ }^{14}$ We use Barro and McCleary (2005) to identify the countries in our sample with Communist regimes in 1970. Additional country-level indicators on GDP per capita in 2003, cumulative educational expenditure per student between age 6 and 15 in 2002, and the existence of curriculum-based external exit exams come from several international statistical sources (see Wößmann, Lüdemann, Schütz, and West 2007).

\footnotetext{
${ }^{13}$ France had to be dropped from the sample because no school-level background information was provided.

${ }^{14}$ We edit the Barrett, Kurian, and Johnson (2001) data on state religion for Austria (which was 92 percent Catholic in 1900), coding it as an officially Catholic country. Although the Austro-Hungarian Compromise of 1867 guaranteed religious liberty, the Catholic Habsburg monarchy maintained a Catholic school system within the boundaries of what is now Austria (Jelavich 1987). All results reported in this paper are robust to the exclusion of Austria from the analysis.
} 
Appendix Table A.1 reports international descriptive statistics for all the variables employed in our analyses. Table A.2 presents country means of selected variables for each participating country.

\section{Results}

This section presents our estimation results on the effect of private school competition on student achievement, followed by robustness specifications and results on effects on educational spending.

\subsection{The Effects of Private School Competition on Student Achievement}

As a point of comparison for the results of our preferred specifications, Table 1 reports the coefficient on the share of PISA 2003 students in a country who attend privately operated schools in a least squares estimation of equation (1). There is a strong and statistically significant positive association between the private school share and student achievement on the PISA 2003 math test, even after controlling for the host of student, family, and school background factors. The estimate is hardly affected by the inclusion of Catholic share in 2000 as a control variable, which enters the model negatively but statistically insignificantly. The average share of funding that private schools receive from government sources, when added to the model as an additional country-level control variable, captures some part of the effect of the private school share. ${ }^{15}$ As is evident from columns (4)-(6) of Table 1, these results hardly change when we restrict the sample to only those countries which are predominantly Christian, defined as having a share of Christians (from different denominations) in 1900 of more than 85 percent. This eliminates Japan (1 percent Christian share), Korea (1 percent), and Turkey (22 percent), countries for which historical Catholic shares are unlikely to be relevant for contemporary private school enrollment.

As discussed above, these least squares estimates may be biased by endogeneity and omitted variables. We therefore turn to the instrumental variable (IV) strategy proposed above, which

15 The variable "government funding share in private schools" is calculated as the average share of funding that the private schools tested in PISA 2003 report that they receive from government sources in each country. Two countries (Australia and Austria) drop out of this specification because their schools did not provide information on the share of funding received from government sources. 
uses only that part of the contemporary international variation in the share of enrollment in privately operated schools that can be explained by historical differences in the Catholic population share.

We first show that there is in fact a strong association between the private school share today and the instrument. This is evident from the second panel of Table 2, which presents estimates of equation (2), the first stage of our IV specification. (Results for all control variables in both the first- and second-stage models are reported in Appendix Table A.1.) The results confirm that the share of students in a country who attend privately operated schools in 2003 is highly correlated with our instrument, the share of Catholics in the population in 1900 interacted with an indicator that Catholicism was not the official state religion. In the basic model presented in column (1), a ten percentage point increase in the Catholic share in 1900 in countries where Catholicism was not the state religion is associated with a 4.7 percent increase in the share of students enrolled in privately operated schools in 2003. The F-statistic of the instrument in the first-stage regression is 13.4, suggesting that our model should not suffer from weak instrument problems (cf. Stock, Wright, and Yogo 2002). The first-stage result supports our basic reasoning above that - as long as Catholics could not be sure that the emerging public school systems of the $19^{\text {th }}$ Century would provide education in line with demands of the Catholic Church - they tended to resist state-provided schools and establish their own private Catholic schools. The consequences of the historical differences in denominational shares persist to the present day.

Note that the significant first-stage association holds even when the share of Catholics in the current population is added to the model in column (2). While the contemporary Catholic share is also significantly associated with the contemporary private school share, the predictive power of the historical Catholic share for our IV strategy is only modestly reduced. When the share of funding that private schools receive from government sources is added as a covariate in column (3), the statistical significance of the relationship increases. While more government funding for privately operated schools does increase the share of students attending privately operated schools, this effect operates independently of the association between the historical Catholic share and the current private school share.

Figure 1 displays the first-stage relationship reported in column (1) of Table 2 as an addedvariable plot aggregated to the country level, the level of variation relevant for our cross-country 
identification strategy. ${ }^{16}$ Though the positive association is evident across the entire sample, three countries - Belgium, Ireland, and the Netherlands - stand out as particularly important in terms of our identifying association. Each had relatively large shares of Catholics in 1900 without Catholicism being the official state religion, and they all built up large private Catholic school systems that have repercussions today. ${ }^{17}$

Turning to the second stage of our IV estimation, the first panel of Table 2 reports the central result of our paper. The estimates show how student achievement in mathematics depends on the extent of competition from privately operated schools in a system. The IV estimate of the effect of the private school enrollment share is positive and statistically significant: A ten percentage point increase in the share of national enrollment in private schools attributable to an historically larger share of Catholics improves math test scores by 9.1 percent of a standard deviation. Given a cross-country standard deviation of the private school share of 0.21 , this result implies that a one standard deviation increase in private school enrollment increases student achievement in math by 19 percent of an international standard deviation in test scores. Due to the clustering of the standard errors at the country level and the thus very limited degrees of statistical freedom at the country level (effectively dealing with 29 independent observations), the statistical precision of the estimate is not very high. The 95 percent confidence interval bounds the effect of a ten percentage point increase in the private school share between 3.9 and 14.2 percent of a standard deviation in test scores. Still, the estimate provides a high degree of confidence that the effect is larger than zero. The basic result is that students in countries whose larger shares of Catholic population in 1900 induced them to have larger shares of privately operated schools today perform significantly better on the PISA 2003 math test.

${ }^{16}$ Added-variable plots show the association between two variables after eliminating the influence of other control variables. Each of the two variables is first regressed on the other controls, and only the residuals from these regressions are used in the graph. The procedure is numerically equivalent to including the other controls in a multivariate regression of private school enrollment share in 2003 on historical Catholic share.

17 Although the first stage loses statistical significance when Belgium, Ireland, and the Netherlands are all excluded from the sample, the least squares estimate on private school share in the second-stage model is actually significantly positive even without these three countries. 
Note that the increase in the estimate from the least squares to the IV specification is consistent with a downward bias of the least squares estimates due to endogeneity. According to this logic, the demand for private alternatives is higher and thus private schools are more likely to be established where the quality of public schools is low.

The second column of Table 2 adds the share of Catholics in the current population as an

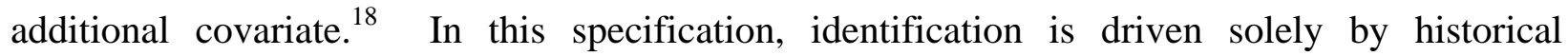
differences in the Catholic share that are not correlated with current differences in the Catholic share - in other words, the change in the Catholic share. ${ }^{19}$ Note that - in line with the historical evidence presented above - adherence to the Catholic faith among the current population is actually negatively associated with student achievement, with an estimate just shy of statistical significance. Together with the fact that the IV estimate of the private school share remains strongly significant in this specification, this increases confidence that our IV estimates indeed capture effects of private competition, rather than effects related to religious adherence. In fact, the coefficient estimate on the private school share increases relative to the specification that does not control for current Catholic adherence, which may suggest that the latter was negatively biased because the historical Catholic share captures a slight negative direct effect of Catholic adherence on student achievement. This only strengthens the result of a positive effect of private school competition. The point estimate of an increase of 12.2 standard deviations in test scores for each ten percentage point increase in the private school share suggests that the true effect may be close to the upper bound of the confidence interval of the estimate discussed above.

As is evident from the first stage of column (3) in Table 2, the share of students attending privately operated schools is also strongly related to the extent to which governments take over

${ }^{18}$ Results are qualitatively unaffected if we use the Catholic share in 2000 interacted with an indicator that Catholicism is not a state religion in 2000 as an alternative control. Also, when added as a control in addition to the Catholic share in 2000, an indicator for Catholic state religion in 2000 does not enter significantly in either the first or second stage of the model and does not change our basic results.

${ }^{19}$ The major source of changes in Catholic shares appears to be secularization, which has disproportionately affected countries that were predominantly Catholic historically. This means that identification in this specification comes primarily from those countries that had higher Catholic shares in 1900 than they have today, which is the type of variation emphasized by our identification strategy. Note that our main results are robust to excluding the Czech Republic, Poland, and the Slovak Republic, three countries with large changes in the Catholic share that may reflect in part changes in borders (as well as the influence of Communism). 
part of the costs of privately operated schools. This raises the question of whether the increased private competition stemming from differences in historical Catholic population shares depends on the latter's impact on state funding rules for privately operated schools. As the second-stage results reveal, controlling for the average share of funding that private schools receive from the government hardly affects the estimate on the private school enrollment share, suggesting that the estimates reported in the first two columns reflect competitive effects stemming from the private operation of schools and not from differences in funding policies.

The estimates reported in columns (4)-(6) of Table 2 show the results are qualitatively unaffected when countries with low shares of Christians are dropped from the sample.

\subsection{Results for Other Subjects and Robustness Checks}

Table 3 reports the equivalents of the math specifications (1)-(3) of Table 2 for student achievement in science and reading. While the estimates of the effect of the private school share on student achievement are somewhat smaller in science and reading than in math, they remain significantly positive. The point estimate from the basic model implies that a change in the historical Catholic population share that translates into a ten percentage point increase in the share of students attending privately operated schools today generates an increase of about 5.5 percent of a standard deviation in both science and reading. The specifications including current Catholic population shares show that this variable is less negatively related to science and especially reading achievement than it is to math achievement.

Table 4 reports additional analyses testing the math results based on the specification

presented in the first column of Table 2 for robustness in different samples. ${ }^{20}$ The first column excludes the countries where Catholicism was the official state religion in 1900. This group includes Austria, Italy, Luxemburg, Portugal, and Spain. Among the remaining countries, the instrument is simply the Catholic population share in 1900 (without an interaction). The firststage association grows even stronger using this sample, and the second-stage result is confirmed.

Column (2) drops two countries - Mexico and Turkey - with particularly low levels of GDP per capita. These countries also stand out by having an average socioeconomic status that is a

${ }^{20}$ All the specifications reported in Table 4 are also robust to including controls for Catholic share in 2000 and government funding share in private schools. 
full standard deviation below the OECD average (as measured by the PISA index of economic, social and cultural status; see Appendix Table A.2). The estimates show that both the first-stage and the second-stage results become slightly stronger when these two countries are excluded from the sample.

Column (3) of Table 4 adds dummies for world regions (Europe, East Asia, North America, and Oceania) to the model. This hardly affects the model at all. Likewise, restricting the analysis to European countries, which have a common Christian heritage divided among various denominations, hardly affects the results (column (4)). We also confirmed that results are robust to dropping each individual country from the analysis one at a time. ${ }^{21}$

Finally, column (5) of Table 4 drops all students attending a privately operated school from the sample in each country, thus estimating the effect of competition from privately operated schools on the performance of students in the public sector. These results are somewhat more difficult to interpret, as they combine competitive effects with the consequences of any crosssector sorting of students with respect to achievement. To the extent that private schools disproportionately attract students with a propensity for higher achievement, the estimated effects of competition will be biased downward by selection. Nonetheless, the results suggest that public school students profit nearly as much from the increased private school competition as students who themselves attend private schools. While the point estimate is somewhat smaller than the analogous result for the full sample reported in column (1) of Table 2, the two estimates are not statistically distinguishable. It becomes clear that a lot of the increased performance of school systems that are exposed to increased private school competition accrues to students who attend public schools.

\subsection{The Effects of Private School Competition on Educational Spending}

The analysis so far has been limited to the outcome side of the educational process, estimating the effect of private school competition on students' educational achievement. In doing so, we have controlled for possible effects of differences in educational inputs such as class sizes, availability of materials, and aggregate expenditure per student in the country. This section turns to the question of whether private school competition also affects the input side of

${ }^{21}$ Although the effect of private competition becomes only marginally significant when Belgium is discarded (primarily because the instrument loses some of its predictive power), the point estimate is essentially unchanged. 
the educational process, again using historical Catholicism as an instrument to obtain exogenous variation in the current private school share. Specifically, we take the country-level measure of cumulative educational expenditure per student up to age 15 (measured in purchasing power parities) as our dependent variable and drop all school-level input measures from our set of explanatory variables.

As the estimates reported in Table 5 reveal, the first-stage results are hardly affected by dropping the input measures from the model. The second-stage results show that private school competition - in addition to raising student achievement - significantly reduces the average spending level of the system. Changes in historical shares of Catholics in the population that are associated with a ten percentage point increase in the private school share today lead to a \$3,209 reduction in cumulative spending per student, or 5.6 percent of the average OECD spending level (of \$56,947).

Competition from private schools therefore appears to increase educational productivity not only by improving student achievement, but also by decreasing the total inputs devoted to education. The productivity of the school system measured as the ratio between output and input increases by even more than is suggested by looking at educational outcomes alone.

\section{Conclusion}

This paper has exploited international variation in the current size of the private school sector stemming from historical differences in the size of the Catholic population. Catholic doctrine in the $19^{\text {th }}$ Century, by resisting the emergence of state school systems and demanding that every Catholic child receive a comprehensive Catholic education, spurred the creation of private Catholic schools in several countries. Although the distinctive Catholic teachings on private education have grown less salient over time, their consequences for the development of national education systems remain evident today. We show that countries with larger shares of Catholics but without an official Catholic state religion in 1900 have significantly larger shares of privately operated schools in 2003, even after controlling for contemporary differences in Catholic population shares. Our estimates suggest that larger historical Catholic shares that translate into a ten percentage point larger private school sector today increase average student achievement on the PISA 2003 math test by at least 9 percent of an international standard deviation. Science and reading achievement increase by at least 5 percent of a standard 
deviation. This is despite the fact that contemporary Catholic shares, which we controlled for in some specifications, are negatively related to student achievement. A large part of the overall achievement improvement in systems with large private school competition appears to accrue to students attending public schools. The natural-experiment framework we develop supports a causal interpretation of these associations, suggesting that competition from privately operated schools leads to better student achievement system-wide.

Not only do school systems with more extensive private sector competition improve educational outcomes, they also do so at lower costs. Our results show that larger Catholic population shares in 1900 that translate into a ten percentage point larger contemporary share of private schools reduce educational expenditure per student by about 5 percent of the average OECD spending. By decreasing inputs at the same time as increasing outcomes, private competition appears to provide a significant boost to the productivity of the school system.

Our results reveal that historical "coincidences" - namely that Catholic resistance to state education in the $19^{\text {th }}$ Century induced larger shares of privately operated schools even today, when such resistance no longer exists in most countries - can have quite unexpected and very long-term consequences. Even though Catholics have historically placed less emphasis on education than, for example, Protestants and Jews (cf. Becker and Wößmann 2008; Botticini and Eckstein 2007), their opposition to state education in many contexts engendered private school competition that ultimately spurred student achievement. 


\section{References}

Acemoglu, Daron, Simon Johnson, James A. Robinson (2001). The Colonial Origins of Comparative Development: An Empirical Investigation. American Economic Review 91 (5): 1369-1401.

Akenson, Donald (1970). The Irish Education Experiment: The National System of Education in the Nineteenth Century. Toronto: University of Toronto Press.

Altonji, Joseph G., Todd E. Elder, Christopher R. Taber (2005). An Evaluation of Instrumental Variable Strategies for Estimating the Effects of Catholic Schooling. Journal of Human Resources 40 (4): 791-821.

Barrett, David B., George T. Kurian, Todd M. Johnson (2001). World Christian Encyclopedia. $2^{\text {nd }}$ edition. Oxford: Oxford University Press.

Barro, Robert J., Rachel M. McCleary (2005). Which Countries Have State Religions? Quarterly Journal of Economics 120 (4): 1331-1370.

Becker, Sascha O., Ludger Wößmann (2008). Was Weber Wrong? A Human Capital Theory of Protestant Economic History. Revised version of CESifo Working Paper 1987. Munich: CESifo.

Belfield, Clive R., Henry M. Levin (2002). The Effects of Competition on Educational Outcomes: A Review of U.S. Evidence. Review of Educational Research 72 (2): 279-341.

Bishop, John H. (2006). Drinking from the Fountain of Knowledge: Student Incentive to Study and Learn - Externalities, Information Problems and Peer Pressure. In: Eric A. Hanushek, Finis Welch (eds.), Handbook of the Economics of Education, Volume 2, pp. 909-944. Amsterdam: North-Holland.

Botticini, Maristella, Zvi Eckstein (2007). From Farmers to Merchants, Conversions and Diaspora: Human Capital and Jewish History. Journal of the European Economic Association 5 (5): 885-926.

Brighouse, Harry (2000). School Choice and Social Justice. Oxford: Oxford University Press.

Card, David, Martin Dooley, A. Abigail Payne (2007). School Competition and Efficiency with Publicly Funded Catholic Schools. Manuscript.

Cohen-Zada, Danny (forthcoming). An Alternative Instrument for Private School Competition. Economics of Education Review: in press.

Dee, Thomas S. (1998). Competition and the Quality of Public Schools. Economics of Education Review 17 (4): 419-427.

Evans, William N., Robert M. Schwab (1995). Finishing High School and Starting College: Do Catholic Schools Make a Difference? Quarterly Journal of Economics 110 (4): 941-974.

Farren, Sean (1995). The Politics of Irish Education: 1920-1965. Belfast: Institute for Irish Studies.

Friedman, Milton (1962). Capitalism and Freedom. Chicago: University of Chicago Press. 
Gallego, Francisco A. (2004). School Choice, Incentives, and Academic Outcomes: Evidence for Chile. Manuscript, Massachusetts Institute of Technology.

Glenn, Charles L. (1988). The Myth of the Common School. Amherst, Mass.: University of Massachusetts Press.

Glenn, Charles L. (1989). Choice of Schools in Six Nations. Washington DC: U.S. Department of Education.

Green, Lowell (1979). The Education of Women in the Reformation. History of Education Quarterly 19 (1): 93-116.

Herbermann, Charles G. (ed.) (1912). The Catholic Encyclopedia: An International Work of Reference on the Constitution, Doctrine, Discipline, and History of the Catholic Church. New York: Robert Appleton Company.

Hoxby, Caroline M. (1994). Do Private Schools Provide Competition for Public Schools? NBER Working Paper 4978. Cambridge, Mass.: National Bureau of Economic Research.

Hoxby, Caroline M. (1996). The Effects of Private School Vouchers on Schools and Students. In Helen Ladd, ed., Holding Schools Accountable: Performance-Based Reform in Education: 177-208. Washington, DC: Brookings Institution Press.

Jelavich, Barbara (1987). Modern Austria: Empire and Republic, 1815-1986. Cambridge: Cambridge University Press.

Jepsen, Christopher (2002). The Role of Aggregation in Estimating the Effects of Private School Competition on Student Achievement. Journal of Urban Economics 52 (3): 477-500.

Jepsen, Christopher (2003). The Effectiveness of Catholic Primary Schooling. Journal of Human Resources 38 (4): 928-941.

Ladd, Helen (2002). School Vouchers: A Critical View. Journal of Economic Perspectives. 16(4): 3-24.

Little, Roderick J.A., Donald B. Rubin (1987). Statistical Analysis with Missing Data. New York: Wiley.

Neal, Derek (1997). The Effects of Catholic Secondary Schooling on Secondary Achievement. Journal of Labor Economics 15 (1): 98-123.

Neal, Derek (2002). How School Vouchers Could Change the Market for Education. Journal of Economic Perspectives 16 (4): 25-44.

Organisation for Economic Co-operation and Development (2004a). Education at a Glance: OECD Indicators 2004. Paris: OECD.

Organisation for Economic Co-operation and Development (2004b). Learning for Tomorrow's World: First Results from PISA 2003. Paris: OECD.

Organisation for Economic Co-operation and Development (2005). PISA 2003 Technical Report. Paris: OECD.

Organisation for Economic Co-operation and Development (2008). OECD Factbook 2008: Economic, Environmental and Social Statistics. Paris: OECD. 
Ramirez, Francisco O., John Boli (1987). The Political Construction of Mass Schooling: European Origins and Worldwide Institutionalization. Sociology of Education 60 (1): 2-17.

Reuben, Julie A. (2005). Patriotic Purposes: Public Schools and the Education of Citizens. In: Susan Fuhrman and Marvin Lazerson (ed.), The Public Schools: 9-24. Oxford: Oxford University Press.

Rupp, Horst F. (1996). Philipp Melanchthon (1497-1560). Prospects: The Quarterly Review of Comparative Education 26 (3): 611-621.

Sander, William (1996). Catholic Grade Schools and Academic Achievement. Journal of Human Resources 31 (3): 540-548.

Sander, William (1999). Private Schools and Public School Achievement. Journal of Human Resources 34 (4): 697-709.

Stock, James H., Jonathan H. Wright, Motohiro Yogo (2002). A Survey of Weak Instruments and Weak Identification in Generalized Method of Moments. Journal of Business and Economic Statistics 20 (4): 518-529.

Toma, Eugenia F. (1996). Public Funding and Private Schooling across Countries. Journal of Law and Economics 39 (1): 121-148.

Vandenberghe, Vincent, Stephane Robin (2004). Evaluating the Effectiveness of Private Education across Countries: A Comparison of Methods. Labour Economics 11 (4): 487-506.

Viteritti, Joseph P. (1998). Blaine's Wake: School Choice, the First Amendment, and State Constitutional Law. Harvard Journal of Law and Public Policy 21 (Summer): 657-718.

West, Martin R. (2000). State Intervention in English Education, 1833-1891: A Public Goods and Agency Approach. Oxford Discussion Papers in Economic and Social History 37 (October).

Wößmann, Ludger (2003). Schooling Resources, Educational Institutions and Student Performance: the International Evidence. Oxford Bulletin of Economics and Statistics 65 (2): 117-170.

Wößmann, Ludger (2008). Public-Private Partnerships and Schooling Outcomes across Countries. In: Raji Chakrabarti, Paul E. Peterson (eds.), School Choice International. Cambridge, Mass.: MIT Press (in press).

Wößmann, Ludger, Elke Lüdemann, Gabriela Schütz, and Martin R. West (2007). School Accountability, Autonomy, Choice, and the Level of Student Achievement: International Evidence from PISA 2003. OECD Education Working Paper 13. Paris: Organisation for Economic Co-operation and Development (OECD). 


\section{Appendix Tables}

\section{Table A.1: Descriptive Statistics and Full Results of Basic Model}

\begin{tabular}{|c|c|c|c|c|c|c|}
\hline & \multicolumn{2}{|c|}{ Descriptive statistics } & \multicolumn{4}{|c|}{ Basic model } \\
\hline & \multirow[t]{2}{*}{ Mean } & \multirow[t]{2}{*}{ Std. dev. } & \multirow{2}{*}{\multicolumn{2}{|c|}{$\begin{array}{c}\text { First stage } \\
\text { (dep. var.: private } \\
\text { school share) } \\
\text { Coeff. Std. Err. }\end{array}$}} & \multicolumn{2}{|c|}{$\begin{array}{c}\text { Second stage } \\
\text { (dep. var.: } \\
\text { PISA math score) }\end{array}$} \\
\hline & & & & & Coeff. & Std. Err. \\
\hline PISA 2003 math score & 499.626 & 100.365 & & & & \\
\hline PISA 2003 science score & 499.239 & 105.252 & & & & \\
\hline PISA 2003 reading score & 494.137 & 100.457 & & & & \\
\hline Private school share & 0.174 & 0.215 & & & $90.625^{* * *}$ & (25.127) \\
\hline Catholic share in 1900 (no state religion) & 0.442 & 0.404 & $0.477^{* * *}$ & $(0.130)$ & & \\
\hline Catholic share in 2000 & 0.404 & 0.354 & & & & \\
\hline Government funding share in private schools & 0.538 & 0.344 & & & & \\
\hline \multicolumn{7}{|l|}{ Student characteristics } \\
\hline Female & 0.496 & & -0.005 & $(0.004)$ & $-16.896^{* * *}$ & (1.624) \\
\hline Age (years) & 15.780 & 0.291 & -0.012 & $(0.023)$ & $21.825^{* * *}$ & $(4.022)$ \\
\hline Preprimary education (more than 1 year) & 0.680 & & $0.052^{* *}$ & $(0.020)$ & 3.651 & $(3.270)$ \\
\hline School starting age & 6.032 & 0.863 & 0.012 & $(0.016)$ & -1.875 & $(2.154)$ \\
\hline Grade repetition in primary school & 0.074 & & $0.068^{*}$ & $(0.039)$ & $-40.908^{* * *}$ & (6.331) \\
\hline Grade repetition in secondary school & 0.062 & & $0.096^{* *}$ & $(0.038)$ & $-38.981^{* * *}$ & $(7.402)$ \\
\hline \multicolumn{7}{|l|}{ Grade } \\
\hline $7^{\text {th }}$ grade & 0.006 & & -0.081 & $(0.071)$ & $-35.578^{* * *}$ & (11.397) \\
\hline $8^{\text {th }}$ grade & 0.047 & & $-0.093^{*}$ & $(0.055)$ & -16.891 & $(10.361)$ \\
\hline $9^{\text {th }}$ grade & 0.359 & & -0.016 & $(0.034)$ & -6.614 & (6.295) \\
\hline $10^{\text {th }}$ grade & 0.526 & & & & & \\
\hline $11^{\text {th }}$ grade & 0.061 & & -0.045 & $(0.050)$ & -3.269 & $(7.215)$ \\
\hline $12^{\text {th }}$ grade & 0.001 & & $-0.132^{* *}$ & $(0.063)$ & 15.787 & $(10.051)$ \\
\hline \multicolumn{7}{|l|}{ Immigration background } \\
\hline Native student & 0.916 & & & & & \\
\hline First generation students & 0.037 & & -0.025 & $(0.021)$ & -6.506 & $(3.990)$ \\
\hline Non-native students & 0.047 & & -0.026 & $(0.021)$ & -7.763 & $(4.956)$ \\
\hline \multicolumn{7}{|l|}{ Language spoken at home } \\
\hline Test language or other official national language & 0.921 & & & & & \\
\hline Other national dialect or language & 0.032 & & 0.026 & $(0.081)$ & $-26.037^{* * *}$ & (7.189) \\
\hline None of above & 0.046 & & -0.015 & $(0.014)$ & $-7.118^{* *}$ & $(3.455)$ \\
\hline \multicolumn{7}{|l|}{ Family background } \\
\hline \multicolumn{7}{|l|}{ Living with } \\
\hline No parent & 0.018 & & & & & \\
\hline Single mother or father & 0.201 & & -0.015 & $(0.015)$ & $22.936^{* * *}$ & $(3.827)$ \\
\hline Patchwork family & 0.064 & & -0.018 & $(0.020)$ & $27.358^{* * *}$ & $(4.638)$ \\
\hline Both parents & 0.717 & & 0.006 & $(0.018)$ & $30.526^{* * *}$ & $(3.700)$ \\
\hline \multicolumn{7}{|l|}{ Parents' working status } \\
\hline Both full-time & 0.391 & & $-0.017^{*}$ & $(0.010)$ & $9.144^{* * *}$ & $(2.483)$ \\
\hline One full-time, one half-time & 0.179 & & -0.004 & $(0.017)$ & $14.433^{* * *}$ & $(2.780)$ \\
\hline At least one full time & 0.293 & & 0.002 & $(0.008)$ & $5.946^{* * *}$ & $(2.096)$ \\
\hline At least one half time & 0.065 & & -0.005 & $(0.011)$ & -3.913 & (2.936) \\
\hline Other (less than one half but not both missing) & 0.071 & & & & & \\
\hline
\end{tabular}




\begin{tabular}{|c|c|c|c|c|c|c|}
\hline Parents' job & & & & & & \\
\hline Blue collar low skilled & 0.095 & & & & & \\
\hline Blue collar high skilled & 0.139 & & $0.012^{*}$ & $(0.006)$ & 1.380 & (1.963) \\
\hline White collar low skilled & 0.234 & & 0.012 & $(0.008)$ & $3.996^{* *}$ & (1.498) \\
\hline White collar high skilled & 0.533 & & 0.012 & $(0.011)$ & $8.572^{* * *}$ & (2.921) \\
\hline Books at home & & & & & & \\
\hline 1-10 books & 0.093 & & & & & \\
\hline 11-25 books & 0.142 & & 0.006 & (0.004) & $5.831^{* * *}$ & (1.817) \\
\hline 26-100 books & 0.310 & & 0.012 & $(0.009)$ & $23.926^{* * *}$ & $(2.030)$ \\
\hline 101-200 books & 0.198 & & 0.016 & $(0.012)$ & $33.316^{* * *}$ & $(2.261)$ \\
\hline 201-500 books & 0.159 & & 0.016 & $(0.013)$ & $50.579^{* * *}$ & (2.684) \\
\hline More than 500 books & 0.098 & & 0.017 & $(0.014)$ & $51.894^{* * *}$ & (3.338) \\
\hline Index of economic, social \& cultural status (ESCS) & -0.001 & 1.007 & $-0.018^{* *}$ & $(0.007)$ & $20.109^{* * *}$ & $(2.036)$ \\
\hline School location and resources & & & & & & \\
\hline School's community location & & & & & & \\
\hline Village or rural area $(<3,000)$ & 0.108 & & & & & \\
\hline Town $(3,000-100,000)$ & 0.568 & & $0.051^{*}$ & $(0.019)$ & 3.047 & $(3.132)$ \\
\hline City $(100,000-1,000,000)$ & 0.213 & & $0.066^{* * *}$ & $(0.023)$ & $9.535^{* *}$ & (3.543) \\
\hline Large city with $>1$ million people & 0.112 & & $0.118^{* * *}$ & $(0.030)$ & 1.424 & $(5.806)$ \\
\hline Class size (mathematics) & 23.206 & 7.621 & 0.001 & $(0.001)$ & $1.363^{* * *}$ & $(0.319)$ \\
\hline Shortage of instructional materials & & & & & & \\
\hline Not at all & 0.380 & & $0.055^{* * *}$ & $(0.019)$ & 3.545 & $(2.170)$ \\
\hline Strongly & 0.070 & & -0.019 & $(0.019)$ & $-6.961^{*}$ & (3.545) \\
\hline Instruction time (mathematics, minutes per week) & 197.874 & 93.651 & -0.000 & $(0.000)$ & $0.028^{*}$ & $(0.016)$ \\
\hline Teacher education (share at school) & & & & & & \\
\hline Fully certified teachers & 0.908 & & 0.061 & $(0.041)$ & 7.180 & $(8.287)$ \\
\hline Tertiary degree in pedagogy & 0.668 & & -0.041 & $(0.070)$ & 5.774 & $(8.001)$ \\
\hline Country-level measures & & & & & & \\
\hline GDP per capita $(1,000 \$)$ & 23.009 & 8.926 & -0.000 & $(0.009)$ & -1.834 & (1.481) \\
\hline Educational expenditure per student $(1,000 \$)$ & 56.947 & 25.507 & -0.001 & $(0.004)$ & $1.462^{* *}$ & $(0.603)$ \\
\hline External exit exams (in math) & 0.650 & 0.450 & 0.147 & $(0.094)$ & 15.196 & (9.289) \\
\hline Communist background & 0.144 & 0.344 & $-0.515^{* * *}$ & $(0.123)$ & 20.255 & (13.632) \\
\hline Observations (students) & & & 219,794 & & 219,794 & \\
\hline Clustering units (countries) & & & 29 & & 29 & \\
\hline$R^{2}$ & & & 0.510 & & 0.373 & \\
\hline
\end{tabular}

Descriptive statistics: Sample: OECD countries (without imputed observations). Mean: international mean (weighted by sampling probabilities). Std. dev.: international standard deviation (only for continuous variables).

Basic model: Full results of the specification reported in the first column of Table 2. Two-stage least squares regression weighted by students' sampling probability. Regression controls for imputation dummies and interaction terms between imputation dummies and the variables. "Catholic share in 1900 (no state religion)" refers to the share of Catholics in the population in 1900 interacted with an indicator of whether Catholicism was the state religion. Robust standard errors adjusted for clustering at the country level in parentheses. Significance level: ${ }^{* * *} 1$ percent, ${ }^{* *}$ 5 percent, ${ }^{*} 10$ percent. 
Table A.2: Country Means of Selected Variables

\begin{tabular}{|c|c|c|c|c|c|c|c|c|c|c|c|}
\hline & \multicolumn{3}{|c|}{ Test scores } & \multirow{2}{*}{$\begin{array}{c}\text { GDP } \\
\text { per } \\
\text { capita } \\
\end{array}$} & \multirow{2}{*}{$\begin{array}{l}\text { Socio- } \\
\text { economic } \\
\text { status } \\
\end{array}$} & \multirow{2}{*}{$\begin{array}{c}\text { Private } \\
\text { school } \\
\text { share }\end{array}$} & \multicolumn{2}{|c|}{ Government funding } & \multirow{2}{*}{$\begin{array}{c}\text { Catholic } \\
\text { share } \\
\text { in } 1900\end{array}$} & \multirow{2}{*}{$\begin{array}{l}\text { Catholic } \\
\text { share } \\
\text { in } 2000\end{array}$} & \multirow{2}{*}{$\begin{array}{c}\text { Catholic } \\
\text { state religion } \\
\text { in } 1900\end{array}$} \\
\hline & Math & Science & Reading & & & & $\begin{array}{l}\text { Private } \\
\text { schools }\end{array}$ & $\begin{array}{l}\text { Public } \\
\text { schools }\end{array}$ & & & \\
\hline Australia & 524.08 & 525.38 & 525.67 & 27,872 & 0.23 & 0.38 & - & - & 0.223 & 0.260 & 0 \\
\hline Austria & 505.10 & 490.98 & 490.91 & 27,567 & 0.05 & 0.08 & - & - & 0.916 & 0.755 & 1 \\
\hline Belgium & 529.09 & 508.20 & 506.99 & 25,262 & 0.14 & 0.69 & 0.851 & 0.966 & 0.974 & 0.809 & 0 \\
\hline Canada & 532.64 & 518.00 & 527.65 & 27,845 & 0.44 & 0.07 & 0.540 & 0.940 & 0.399 & 0.391 & 0 \\
\hline Czech Republic & 516.06 & 522.18 & 488.04 & 14,642 & 0.15 & 0.07 & 0.634 & 0.969 & 0.862 & 0.404 & 0 \\
\hline Denmark & 513.74 & 474.41 & 491.21 & 27,970 & 0.20 & 0.22 & 0.756 & 0.981 & 0.002 & 0.006 & 0 \\
\hline Finland & 544.17 & 547.53 & 542.90 & 23,786 & 0.24 & 0.07 & 0.979 & 0.999 & 0.000 & 0.001 & 0 \\
\hline Germany & 503.08 & 502.62 & 491.70 & 25,189 & 0.15 & 0.08 & 0.782 & 0.978 & 0.357 & 0.335 & 0 \\
\hline Greece & 444.55 & 480.66 & 471.58 & 15,787 & -0.16 & 0.04 & 0.000 & 0.901 & 0.013 & 0.004 & 0 \\
\hline Hungary & 490.34 & 504.02 & 481.87 & 13,016 & -0.07 & 0.11 & 0.779 & 0.927 & 0.606 & 0.609 & 0 \\
\hline Iceland & 514.71 & 494.50 & 491.73 & 26,352 & 0.69 & 0.00 & 0.897 & 0.977 & 0.000 & 0.010 & 0 \\
\hline Ireland & 503.48 & 506.20 & 515.82 & 28,247 & -0.08 & 0.61 & 0.448 & 0.999 & 0.887 & 0.847 & 0 \\
\hline Italy & 465.77 & 486.30 & 474.94 & 22,924 & -0.11 & 0.05 & 0.135 & 0.746 & 0.996 & 0.798 & 1 \\
\hline Japan & 533.64 & 548.14 & 499.04 & 24,036 & -0.08 & 0.27 & 0.327 & 0.895 & 0.001 & 0.004 & 0 \\
\hline Korea & 541.63 & 538.46 & 534.71 & 17,595 & -0.10 & 0.56 & 0.552 & 0.475 & 0.005 & 0.069 & 0 \\
\hline Luxembourg & 493.28 & 482.81 & 478.58 & 49,261 & 0.19 & 0.14 & 0.885 & 0.988 & 0.966 & 0.902 & 1 \\
\hline Mexico & 384.86 & 403.53 & 399.53 & 7,939 & -1.14 & 0.16 & 0.008 & 0.453 & 0.908 & 0.900 & 0 \\
\hline Netherlands & 538.06 & 524.91 & 513.96 & 26,154 & 0.08 & 0.77 & 0.956 & 0.954 & 0.351 & 0.345 & 0 \\
\hline New Zealand & 524.08 & 521.81 & 521.99 & 22,197 & 0.21 & 0.05 & 0.150 & 0.808 & 0.135 & 0.128 & 0 \\
\hline Norway & 495.35 & 484.93 & 499.68 & 34,013 & 0.61 & 0.01 & 0.883 & 0.997 & 0.001 & 0.010 & 0 \\
\hline Poland & 490.10 & 497.86 & 496.48 & 9,2171 & -0.21 & 0.01 & 0.353 & 0.964 & 0.771 & 0.922 & 0 \\
\hline Portugal & 466.14 & 468.46 & 477.76 & 17,333 & -0.64 & 0.06 & 0.643 & 0.853 & 0.998 & 0.887 & 1 \\
\hline Slovak Republic & 498.63 & 494.67 & 469.24 & 10,943 & -0.09 & 0.12 & 0.935 & 0.921 & 0.847 & 0.679 & 0 \\
\hline Spain & 485.57 & 487.48 & 481.68 & 20,642 & -0.30 & 0.38 & 0.670 & 0.958 & 1.000 & 0.917 & 1 \\
\hline Sweden & 509.59 & 506.33 & 514.32 & 26,138 & 0.25 & 0.04 & 0.989 & 0.998 & 0.000 & 0.019 & 0 \\
\hline Switzerland & 526.09 & 513.11 & 498.61 & 28,792 & -0.06 & 0.06 & 0.222 & 0.989 & 0.399 & 0.429 & 0 \\
\hline Turkey & 423.80 & 434.64 & 441.68 & 5,634 & -0.99 & 0.03 & 0.000 & 0.559 & 0.005 & 0.001 & 0 \\
\hline United Kingdom & 508.02 & 518.20 & 506.81 & 26,044 & 0.11 & 0.06 & 0.129 & 0.986 & 0.064 & 0.093 & 0 \\
\hline United States & 483.49 & 491.59 & 494.87 & 34,875 & 0.29 & 0.06 & 0.020 & 0.928 & 0.142 & 0.182 & 0 \\
\hline
\end{tabular}

Country means, based on non-imputed data for each variable, weighted by sampling probabilities. Socioeconomic status = PISA index of economic, social and cultural status (ESCS). Institutional and demographic measures are population shares within each country. $-=$ not available 
Figure 1: Historical Catholic Share and Contemporary Private Schooling

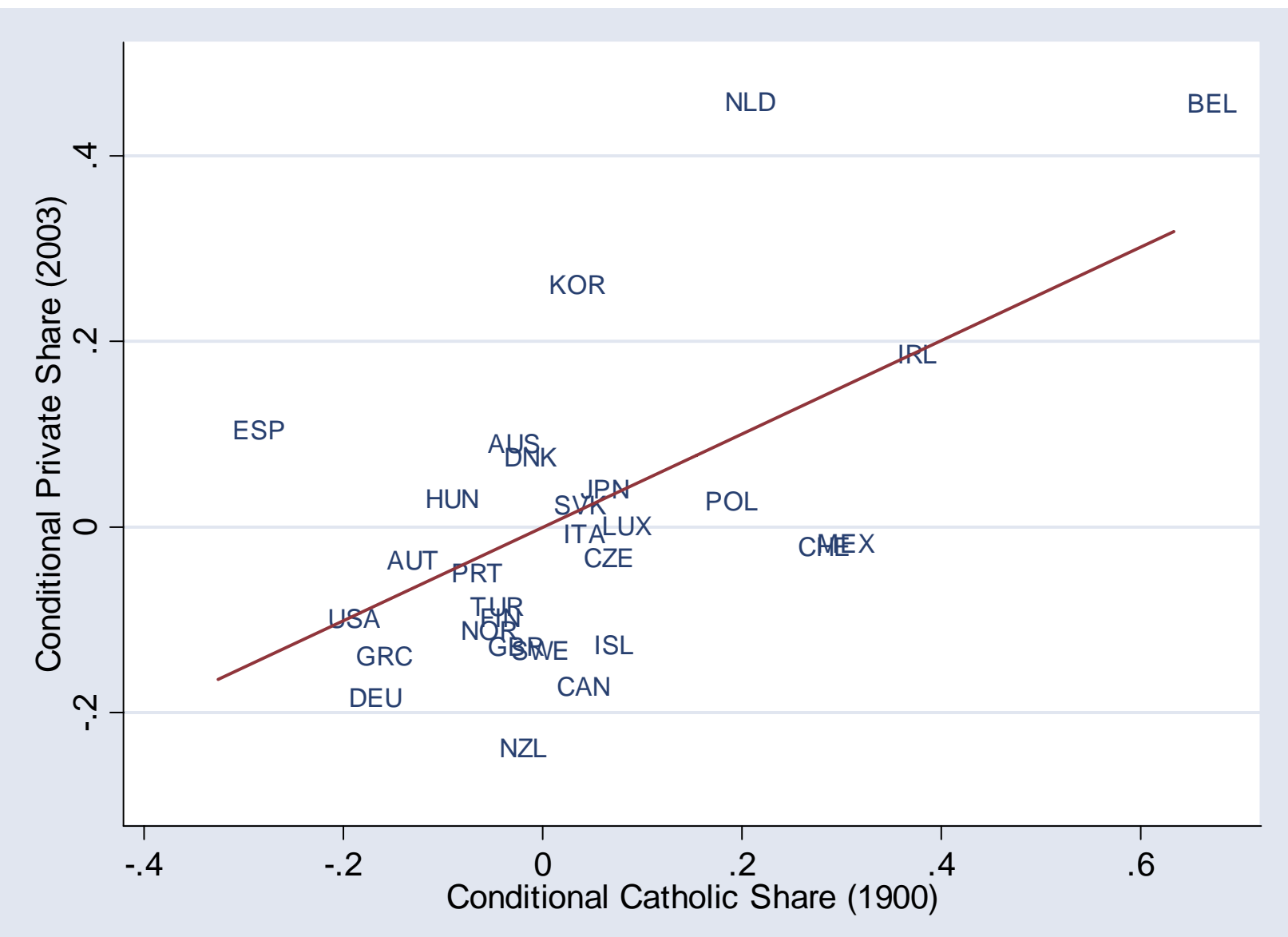

Notes: Added-variable plot of a regression of the share of PISA 2003 students enrolled in privately operated schools on Catholic population share in 1900 (interacted with an indicator whether Catholicism was the state religion) and all the control variables included in equation (2). Based on a student-level regression (equivalent to the first column of Table 2) that is then aggregated to the country level. 
Table 1: Least Squares Results

\begin{tabular}{lccc|ccc}
\hline \hline & \multicolumn{3}{c}{ OECD countries } & \multicolumn{3}{c}{ Predominantly Christian countries } \\
& $(1)$ & $(2)$ & $(3)$ & $(4)$ & $(5)$ & $(6)$ \\
\hline Private school share & $52.530^{* * *}$ & $55.765^{* * *}$ & $38.521^{* *}$ & $53.349^{* * *}$ & $57.867^{* * *}$ & $38.091^{* *}$ \\
& $(13.573)$ & $(14.012)$ & $(14.332)$ & $(14.460)$ & $(15.372)$ & $(14.655)$ \\
Catholic share in 2000 & - & -5.592 & -12.946 & - & -6.641 & -13.760 \\
& - & $(13.283)$ & $(12.468)$ & - & $(13.942)$ & $(13.186)$ \\
Government funding share & - & - & $34.580^{* *}$ & - & - & $37.231^{* *}$ \\
$\quad$ in private schools & - & - & $(13.948)$ & - & - & $(14.880)$ \\
\hline Observations (students) & 219,794 & 219,794 & 202,646 & 204,788 & 204,788 & 187,640 \\
Clustering units (countries) & 29 & 29 & 27 & 26 & 26 & 24 \\
$R^{2}$ & 0.377 & 0.377 & 0.385 & 0.370 & 0.370 & 0.379 \\
\hline \hline
\end{tabular}

Dependent variable: PISA 2003 math score. Least squares regressions weighted by students' sampling probability. All regressions control for: 15 student characteristics, 16 family background measures, 9 measures of school location and resources, GDP per capita, expenditure per student, external exit exams, Communist background, imputation dummies, and interaction terms between imputation dummies and the variables. "Predominantly Christian countries" refers to countries with a share of adherence to Christian denominations of more than 85 percent in 1900. Robust standard errors adjusted for clustering at the country level in parentheses. Significance level: ${ }^{* * *} 1$ percent, ${ }^{* *} 5$ percent, ${ }^{*} 10$ percent. 
Table 2: Instrumental Variable Results: Math Achievement

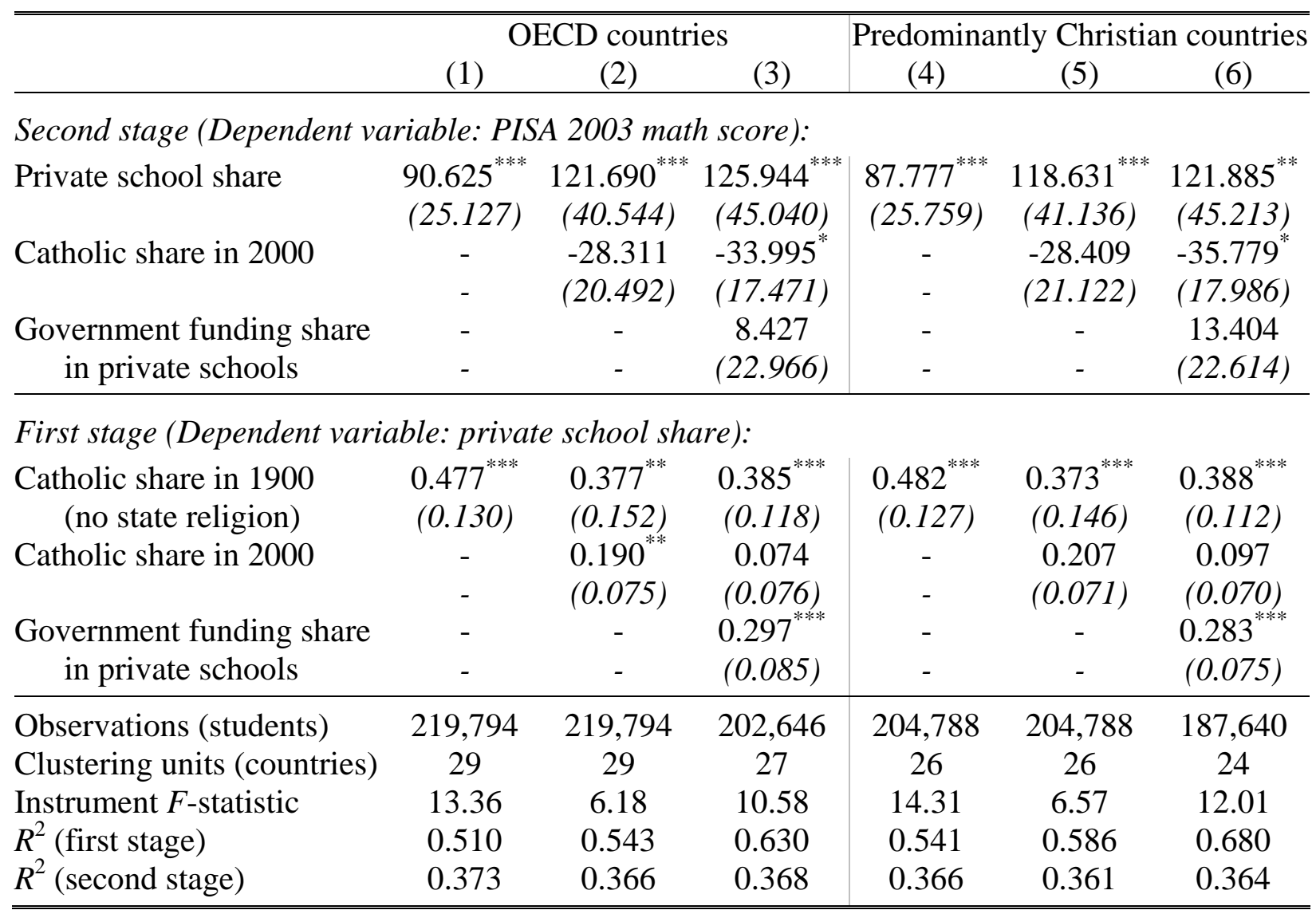

Two-stage least squares regressions weighted by students' sampling probability. All regressions control for: 15 student characteristics, 16 family background measures, 9 measures of school location and resources, GDP per capita, expenditure per student, external exit exams, Communist background, imputation dummies, and interaction terms between imputation dummies and the variables. "Predominantly Christian countries" refers to countries with a share of adherence to Christian denominations of more than 85 percent in 1900. "Catholic share in 1900 (no state religion)" refers to the share of Catholics in the population in 1900 interacted with an indicator of whether Catholicism was the state religion. Robust standard errors adjusted for clustering at the country level in parentheses. Significance level: ${ }^{* * *} 1$ percent, ${ }^{* *} 5$ percent, ${ }^{*} 10$ percent. 
Table 3: Instrumental Variable Results: Science and Reading Achievement

\begin{tabular}{lccc|ccc}
\hline \hline & & \multicolumn{3}{c}{ Science } & \multicolumn{3}{c}{ Reading } \\
& $(1)$ & $(2)$ & $(3)$ & $(4)$ & $(5)$ & $(6)$ \\
\hline Private school share & $56.843^{* * *}$ & $74.640^{* *}$ & $70.791^{*}$ & $55.494^{* * *}$ & $58.985^{*}$ & $56.835^{*}$ \\
& $(20.511)$ & $(34.762)$ & $(34.978)$ & $(17.238)$ & $(29.642)$ & $(32.964)$ \\
Catholic share in 2000 & - & -16.219 & -16.600 & - & -3.181 & -6.717 \\
& - & $(16.413)$ & $(13.362)$ & - & $(16.350)$ & $(14.922)$ \\
Government funding share & - & - & 5.716 & - & - & 11.616 \\
$\quad$ in private schools & - & - & $(19.184)$ & - & - & $(19.521)$ \\
\hline Observations (students) & 219,794 & 219,794 & 202,646 & 219,794 & 219,794 & 202,646 \\
Clustering units (countries) & 29 & 29 & 27 & 29 & 29 & 27 \\
$R^{2}$ (second stage) & 0.331 & 0.329 & 0.329 & 0.355 & 0.355 & 0.353 \\
\hline \hline
\end{tabular}

Dependent variable: PISA 2003 science/reading score. Sample: OECD countries. Second stage of two-stage least squares regressions weighted by students' sampling probability (see Table 2 for first-stage results). All regressions control for: 15 student characteristics, 16 family background measures, 9 measures of school location and resources, GDP per capita, expenditure per student, external exit exams (using subject-specific data for science), Communist background, imputation dummies, and interaction terms between imputation dummies and the variables. "Catholic share in 1900 (no state religion)" refers to the share of Catholics in the population in 1900 interacted with an indicator of whether Catholicism was the state religion. Robust standard errors adjusted for clustering at the country level in parentheses. Significance level: ${ }^{* * *} 1$ percent, ${ }^{* *} 5$ percent, ${ }^{*} 10$ percent. 
Table 4: Robustness Analyses

\begin{tabular}{|c|c|c|c|c|c|}
\hline Sample of countries: & $\begin{array}{l}\text { No Catholic } \\
\text { state religion } \\
(1)\end{array}$ & $\begin{array}{l}\text { GDP p.c. }> \\
\$ 9000 \\
(2)\end{array}$ & $\begin{array}{c}\text { OECD w/ } \\
\text { region dummies } \\
(3)\end{array}$ & $\begin{array}{c}\text { Europe } \\
\text { only } \\
(4)\end{array}$ & $\begin{array}{c}\text { Public school } \\
\text { students only } \\
\text { (5) }\end{array}$ \\
\hline \multicolumn{6}{|c|}{ Second stage (Dependent variable: PISA 2003 math score): } \\
\hline Private school share & $\begin{array}{l}91.814^{* * *} \\
(20.824)\end{array}$ & $\begin{array}{c}105.281^{* * *} \\
(24.833)\end{array}$ & $\begin{array}{l}92.295^{* * *} \\
(25.805)\end{array}$ & $\begin{array}{l}96.948^{* * *} \\
(24.469)\end{array}$ & $\begin{array}{l}66.529^{* *} \\
(24.419)\end{array}$ \\
\hline \multicolumn{6}{|c|}{ First stage (Dependent variable: private school share): } \\
\hline $\begin{array}{l}\text { Catholic share in } 1900 \\
\text { (no state religion) }\end{array}$ & $\begin{array}{c}0.637^{* * *} \\
(0.113)\end{array}$ & $\begin{array}{l}0.578^{* * *} \\
(0.113)\end{array}$ & $\begin{array}{l}0.473^{* * *} \\
(0.110)\end{array}$ & $\begin{array}{l}0.552^{* * *} \\
(0.117)\end{array}$ & $\begin{array}{l}0.486^{* * *} \\
(0.129)\end{array}$ \\
\hline Observations (students) & 195,875 & 185,956 & 219,794 & 129,189 & 169,255 \\
\hline Clustering units (countries) & 25 & 27 & 29 & 22 & $28^{\mathrm{a}}$ \\
\hline Instrument $F$-statistic & 31.62 & 26.30 & 18.64 & 22.48 & 14.17 \\
\hline$R^{2}$ (first stage) & 0.597 & 0.585 & 0.656 & 0.675 & 0.520 \\
\hline$R^{2}$ (second stage) & 0.373 & 0.327 & 0.373 & 0.361 & 0.383 \\
\hline
\end{tabular}

Sample: OECD countries. Two-stage least squares regressions weighted by students' sampling probability. All regressions control for: 15 student characteristics, 16 family background measures, 9 measures of school location and resources, GDP per capita, expenditure per student, external exit exams, Communist background, imputation dummies, and interaction terms between imputation dummies and the variables. "Catholic share in 1900 (no state religion)" refers to the share of Catholics in the population in 1900 interacted with an indicator of whether Catholicism was the state religion. Region dummies used in column (3) include Europe, East Asia, North America, and Oceania. "Public school students only" drops all students enrolled in privately operated schools from the sample. ${ }^{a}$ School-level information on private operation is not available for Australia. Robust standard errors adjusted for clustering at the country level in parentheses. Significance level: ${ }^{* * *} 1$ percent, ${ }^{* *} 5$ percent, ${ }^{*} 10$ percent. 
Table 5: Private School Competition and Expenditure per Student

\begin{tabular}{|c|c|c|c|c|c|c|}
\hline & \multicolumn{3}{|c|}{ OECD countries } & \multicolumn{3}{|c|}{ Predominantly Christian countries } \\
\hline & (1) & (2) & (3) & (4) & (5) & (6) \\
\hline \multicolumn{7}{|c|}{ Second stage (Dependent variable: expenditure per student in 2003): } \\
\hline Private school share & $\begin{aligned}-32.089^{* *} \\
(15.031)\end{aligned}$ & $\begin{array}{l}-45.736^{*} \\
(23.329)\end{array}$ & $\begin{array}{c}-48.863^{* *} \\
(23.388)\end{array}$ & \begin{tabular}{|l}
$-29.797^{* *}$ \\
$(13.635)$
\end{tabular} & $\begin{array}{l}-42.416^{* *} \\
(20.529)\end{array}$ & $\begin{array}{c}-44.832^{* *} \\
(19.528)\end{array}$ \\
\hline Catholic share in 2000 & - & $\begin{array}{l}16.068^{* * *} \\
(6.135)\end{array}$ & $\begin{array}{l}13.933^{* * *} \\
(5.904)\end{array}$ & - & $\begin{array}{l}15.889^{* * *} \\
(5.820)\end{array}$ & $\begin{array}{l}14.172^{* * *} \\
(5.608)\end{array}$ \\
\hline $\begin{array}{l}\text { Povernment funding share } \\
\text { in private schools }\end{array}$ & - & - & $\begin{array}{c}9.071 \\
(7.437)\end{array}$ & $\begin{array}{l}- \\
-\end{array}$ & $\begin{array}{l}- \\
-\end{array}$ & $\begin{array}{c}8.060 \\
(6.004)\end{array}$ \\
\hline \multicolumn{7}{|c|}{ First stage (Dependent variable: private school share): } \\
\hline $\begin{array}{l}\text { Catholic share in } 1900 \\
\text { (no state religion) }\end{array}$ & $\begin{array}{c}0.437^{* * *} \\
(0.128)\end{array}$ & $\begin{array}{c}0.372^{* * *} \\
(0.134)\end{array}$ & $\begin{array}{c}0.331^{* * *} \\
(0.104)\end{array}$ & $\begin{array}{l}0.460^{* * *} \\
(0.122)\end{array}$ & $\begin{array}{c}0.392^{* * *} \\
(0.128)\end{array}$ & $\begin{array}{c}0.354^{* * *} \\
(0.093)\end{array}$ \\
\hline Catholic share in 2000 & - & $\begin{array}{l}0.177^{* *} \\
(0.075)\end{array}$ & $\begin{array}{c}0.086 \\
(0.074)\end{array}$ & - & $\begin{array}{l}0.185^{* *} \\
(0.080)\end{array}$ & $\begin{array}{c}0.096 \\
(0.074)\end{array}$ \\
\hline $\begin{array}{l}\text { Government funding share } \\
\text { in private schools }\end{array}$ & - & - & $\begin{array}{l}0.301^{* * *} \\
(0.092)\end{array}$ & - & $\begin{array}{l}- \\
-\end{array}$ & $\begin{array}{l}0.312^{* * *} \\
(0.086)\end{array}$ \\
\hline Obser & 219,794 & 219,794 & 202,646 & 204,788 & 204,788 & 187,640 \\
\hline nits (countries) & 29 & 29 & 27 & 26 & 26 & 24 \\
\hline t F-statistic & 11.66 & 7.67 & 10.07 & 14.13 & 9.32 & 14.35 \\
\hline & 0.437 & 0.469 & 0.579 & 0.471 & 0.512 & 0.647 \\
\hline$R^{2}$ (second stage) & 0.902 & 0.879 & 0.874 & 0.906 & 0.896 & 0.896 \\
\hline
\end{tabular}

Two-stage least squares regressions weighted by students' sampling probability. All regressions control for: 15 student characteristics, 16 family background measures, 4 measures of school location, GDP per capita, external exit exams, Communist background, imputation dummies, and interaction terms between imputation dummies and the variables. "Predominantly Christian countries" refers to countries with a share of adherence to Christian denominations of more than 85 percent in 1900. "Catholic share in 1900 (no state religion)" refers to the share of Catholics in the population in 1900 interacted with an indicator of whether Catholicism was the state religion. Robust standard errors adjusted for clustering at the country level in parentheses. Significance level: ${ }^{* * *} 1$ percent, ${ }^{* *}$ 5 percent, ${ }^{*} 10$ percent. 